\title{
Ryegrass endophyte: a New Zealand Grassland success story
}

\author{
H.S. EASTON ${ }^{1}$, M.J. CHRISTENSEN 1 , J.P.J. EERENS ${ }^{2}$, L.R. FLETCHER ${ }^{3}$, D.E. HUME ${ }^{1}$, \\ R.G. KEOGH ${ }^{1}$, G.A. LANE ${ }^{1}$, G.C.M. LATCH ${ }^{1}$, C.G.L. PENNELL ${ }^{3}$, A.J. POPAY ${ }^{2}$, \\ M.P. ROLSTON ${ }^{3}$, B.L. SUTHERLAND ${ }^{3}$ and B.A. TAPPER ${ }^{1}$ \\ ${ }^{1}$ AgResearch Grasslands, Private Bag 11008, Palmerston North \\ ${ }^{2}$ AgResearch Ruakura, Private Bag, Hamilton \\ ${ }^{3}$ AgResearch Lincoln, P.O. Box 60, Lincoln \\ ${ }^{1}$ sydney.easton@agresearch.co.nz
}

\begin{abstract}
The discovery in 1981 that ryegrass endophyte is responsible for ryegrass staggers has required a total revision of our understanding of ryegrassbased pastures. The effects on grazing livestock range from obvious clinical disorders to chronic impairment of productivity. On the other hand, endophyte infection is essential to ryegrass persistence in most of New Zealand, protecting the plant from some invertebrate pests and from over-grazing, and perhaps promoting its tolerance of moisture stress. Vigorous, endophyte-infected pastures sometimes include less clover than pastures relatively free of endophyte. Active compounds produced by the endophyte have been identified, and conditions causing high levels of them have been documented in part. Endophyte strains which do not produce the compounds responsible for livestock toxicoses offer exciting new possibilities in grassland agriculture.
\end{abstract}

Keywords: invertebrate pests, mycotoxicoses, Neotyphodium lolii, perennial ryegrass, ryegrass staggers

\section{Introduction}

Perennial ryegrass (PRG) is the most widely-sown species in New Zealand pastures and has been intensively researched since the 1920 s (Hunt \& Easton 1989). However, as late as 1980 , the discoveries that the endophytic fungus, Neotyphodium lolii, caused ryegrass staggers (Fletcher \& Harvey 1981) and protected the plant from Argentine stem weevil (ASW) (Prestidge et al. 1982) have required a total reexamination of all we thought we knew about ryegrass pastures. Endophyte research has also enabled us to revise our understanding of tall fescue, a redoubtable toxic weed dominating our roadsides and other waste places.

The endophytic fungi in PRG and tall fescue had been described in 1933 (Sampson 1933) and further studied in the 1940s by New Zealand scientists (Neill
1941), and the possibility that they caused livestock disorders was raised and investigated (Cunningham 1958). However, the experiments failed to make the suggested link, and another 20 years passed before the significance of the endophytes was established.

The crucial initial discoveries were serendipitous. Since then, endophyte research has been focused and multidisciplinary, but founded on the experience and expertise already present in our research groups. Another feature of the work has been the importance of international contacts, and in particular the close and very fruitful interchange with research groups in the south east of the USA.

\section{Ryegrass staggers and animal health}

Sheep grazing different seed-lines of PRG in an experiment at Lincoln were very differently affected by ryegrass staggers. The pasture causing the worst staggers had high levels of infection with endophyte, while the sheep free of staggers were grazing a pasture with almost no endophyte (Fletcher \& Harvey 1981; Fletcher 1982). This led to an intensive programme documenting and quantifying the effects of endophyte on sheep (Table 1). The precise effects of the staggers toxin on nerve and muscle function (McLeay \& Smith 1999; Munday-Finch \& Garthwaite 1999) have been described, and genetic resistance in sheep has been measured (Morris et al. 1999).

Ryegrass staggers is the most obvious and immediately serious effect, but many other indicators of sheep health and productivity are affected. Notable among these are the effects on liveweight gain, on serum prolactin levels and on body temperature control. Liveweight gain of lambs, pre- and post-weaning, and of older sheep has been shown to be depressed by grazing endophyte-infected PRG (Fletcher et al. 1999). Depression in gain of more than $30 \%$, sustained over many weeks, has been recorded for hoggets, and of up to $90 \%$ for lambs.

Serum prolactin concentration in sheep responds to ambient temperature, with levels rising from typically below $50 \mathrm{ng} / \mathrm{ml}$ at moderate temperatures, to above $200 \mathrm{ng} / \mathrm{ml}$ in warm conditions. Sheep grazing endo- 
phyte-infected PRG do not respond in this way, so that at higher temperatures, there is a wide difference between animals grazing infected and endophyte-free herbage (Fletcher et al. 1997). These results conform to published American reports of cattle grazing tall fescue. Depression of serum prolactin is now recognised as a sensitive indicator of exposure of livestock to endophyte-related toxicity.

Animals grazing endophyte-infected PRG frequently show a higher body temperature, particularly when held in conditions of high ambient temperature and humidity, the difference sometimes being a full Celsius degree. Associated with this, sheep grazing endophyteinfected PRG may exhibit severe panting (Fletcher et al. 1999).

Ryegrass staggers is a problem specific to ryegrass pastures, but other endophyte-related symptoms in livestock are similar to some effects of infected tall fescue, with some of the same compounds involved (see below).

\section{Pest protection and persistence}

In a trial established at Ruakura to compare stock performance on infected and endophyte-free pasture, the endophyte-free sward was severely damaged by ASW (Prestidge et al. 1982). Subsequent work established the crucial role played by endophyte in ensuring the persistence of PRG (Table 2) and the reputation of the species as well adapted to New Zealand. Without endophyte, PRG swards in Waikato, Canterbury and some other districts simply did not persist (Mortimer \& di Menna 1983; Prestidge \& Ball 1993; Popay \& Rowan 1994). Both field plots and glasshouse pot experiments have been used in this work.

The resistance of endophyte-infected PRG to ASW is based on deterring the adult weevil from feeding (Barker et al. 1984b). Fewer eggs are laid (Gaynor $\&$ Hunt 1983) so that larval numbers are lower. The compound peramine, produced by the endophyte and translocated through the shoot system, provides this deterrence. Peramine in the seed coat is translocated after germination through the emerging seedling, deterring insect feeding in the early period of growth (Stewart 1985; Ball et al. 1993).

ASW larvae are not deterred from feeding, but growth rates and survival of larvae are lower on endophyte-infected than endophyte-free PRG (Barker et al. 1984a).

Table 1 Major discoveries of effects of endophyte-infected ryegrass herbage on health and performance of grazing livestock.

\begin{tabular}{|c|c|}
\hline Discovery & Reference \\
\hline Lolium endophyte causes ryegrass staggers & Fletcher \& Harvey (1981) \\
\hline Lolium endophyte reduces rate of liveweight gain in lambs grazing PRG & Fletcher (1983) \\
\hline $\begin{array}{l}\text { Lolium endophyte in PRG depressed serum prolactin in lambs; a link established } \\
\text { between ryegrass and fescue toxicosis }\end{array}$ & Fletcher \& Barrell (1984) \\
\hline $\begin{array}{l}\text { The first lolitrem-free endophyte in PRG evaluated, showing possible elimination } \\
\text { of ryegrass staggers. }\end{array}$ & Fletcher et al. (1991) \\
\hline Lolium endophyte linked to faecal contamination (dags) & Fletcher (1993); Pownall et al. (1993) \\
\hline $\begin{array}{l}\text { Livestock grazing herbage infected with AR1 endophyte strain, free of ergovaline } \\
\text { and lolitrem B, are free of all toxic effects. }\end{array}$ & Fletcher \& Easton (1997) \\
\hline Sheep can be bred for resistance to RGS & Morris et al. (1999) \\
\hline Milk production of dairy cows sometimes affected by endophyte & $\begin{array}{l}\text { Blackwell \& Keogh (1999); Clark et al. (1996); } \\
\text { Thom et al. (1999) }\end{array}$ \\
\hline $\begin{array}{l}\text { Metabolites other than lolitrem B in ryegrass/endophyte associations can cause } \\
\text { staggers symptoms in grazing livestock. }\end{array}$ & $\begin{array}{l}\text { Fletcher \& Tapper, unpublished data (1991, } \\
\text { 2001) }\end{array}$ \\
\hline
\end{tabular}

Table 2 Major discoveries of endophyte effects on pasture invertebrates.

\begin{tabular}{ll}
\hline Discovery & Reference \\
\hline Ryegrass infected with wild-type endophyte is resistant to Argentine stem weevil & Prestidge et al. (1982) \\
(ASW) & Rowan \& Gaynor (1986) \\
The ASW feeding deterrent, peramine, is isolated from wild-type-infected ryegrass & Dymock et al. (1989) \\
Lolitrem B affects ASW larvae growth and development & Popay et al. (1990) \\
Ergovaline deters adult ASW & Fletcher et al. (1991) \\
Lolitrem-free endophytes give resistance to ASW & Ball \& Prestidge (1992) \\
Black beetle adults are deterred by wild-type endophyte & Ball et al. (1997) \\
Ergovaline is identified as a major factor in black beetle resistance & Popay et al. (1999) \\
AR1-infected ryegrass is as resistant to ASW as wild-type & Pennell (1998) unpublished data; Popay et al. \\
Ryegrass with endophyte, including AR1, is resistant to a pasture mealy bug & (2000) \\
Ryegrass with AR1 has some resistance to black beetle & Popay \& Baltus (2001) \\
\hline
\end{tabular}


ASW is not the only invertebrate pest sensitive to endophyte. Black beetle (Heteronychus arator) is sporadically serious in northern New Zealand, attacking PRG pastures if they are free of endophyte, and several other grass species. However, infected PRG is not severely attacked (Ball \& Prestidge 1992).

Recent data have revealed the sensitivity to endophyte of the pasture mealy bug (Balanococcus poae), and the severe effects this little-known insect can have on endophyte-free PRG pastures, particularly after a dry summer (Pennell \& Ball 1999; Popay et al. 2001).

Other invertebrate research has studied root- and soil-dwelling nematode species (Eerens et al. 1998b; Watson 1990; Stewart et al. 1993; Watson et al. 1995), several other pasture pests and beneficial soil invertebrates such as earthworms (Prestidge \& Marshall 1997; Prestidge et al. 1997). None of these have shown the clear response to endophyte established for ASW, black beetle and pasture mealy bug.

Direct enhancement of PRG growth by endophyte was documented by Latch et al. (1985), but other experiments (Barker et al. 1997; Hume et al. 1993) (D.E. Hume, H.S. Easton \& M.P. Rolston, unpublished data) have not shown this. Endophyte-infected PRG competed more aggressively with associated white clover (Sutherland \& Hoglund 1989; Stevens \& Hickey 1990; Sutherland et al. 1999), and a direct suppressing factor released from grass litter has been suggested. However, most of the effect can be ascribed to greater grass vigour, arising from protection from invertebrate pests and over-grazing (Prestidge et al. 1992).

American scientists have identified pests that are sensitive to endophyte, but do not consider this the major factor in the superior persistence of endophyteinfected fescue. Their research has focused on direct effects of the fungus on grass growth and drought tolerance. In contrast, we consider in New Zealand that pest protection is the primary component of superior productivity and persistence of endophyte-infected PRG pastures.

The incidence of invertebrate pests varies with regional conditions, and a number of trials have shown no yield or persistence advantages to endophyte-infected ryegrass in Southland (Eerens et al. 1998a). Endophytefree ryegrass can be used in parts of that region.

\section{Chemical compounds}

Before 1980, it was thought likely that a fungus was involved with ryegrass staggers, and research aimed to isolate the chemical compound(s) responsible. The discovery of the role of the endophyte hastened this process, and lolitrem $\mathrm{B}$ was isolated and described
(Gallagher et al. 1981). Several related compounds have been identified, but lolitrem B is the most abundant and perhaps the most potent (Miles et al. 1994). The main compound responsible for protection from ASW was shown to be different, and peramine was isolated and described (Rowan \& Gaynor 1986). USA research had identified ergovaline as the primary fescue toxin, and this compound was later found in endophyte-infected PRG (Rowan \& Shaw 1987). Ergovaline and lolitrem B, primarily studied for their effects on livestock, also offer protection against invertebrate pests (Dymock et al. 1989; Ball et al. 1997). Co-evolution of endophyte and host is reflected in the array of compounds occurring in different endophyte-infected grasses (Lane et al. 2000).

Techniques for determination of levels of chemicals in samples have improved, in accuracy, in the numbers processed with the same resource, and in the ability to analyse very small samples so that the precise location can be determined (B.A. Tapper, unpublished data) (Davies et al. 1993; Spiering 2000).

\section{Cattle research}

There has been significantly less work on cattle than on sheep. Depressed serum prolactin has been recorded in cattle grazing endophyte-infected PRG (Blackwell \& Keogh 1999; Easton \& Couchman 1999). It was argued that heat stress in cattle in northern New Zealand ascribed to tall fescue was probably often owing to endophyte-infected PRG (Easton et al. 1996). A series of trials conducted by Dexcel (formerly Dairying Research Corporation) showed that any effects on dairy cows were irregular and probably minor (Thom et al. 1999). However, an on-farm study in Northland, following a split herd through a whole season, indicated $20 \%$ greater milk production per cow on ryegrass pasture free of endophyte toxins than on naturally infected pasture in the first year (Blackwell \& Keogh 1999) and 5\% and 8\% greater production in the second and third seasons (Blackwell $\&$ Keogh 2001). The areas and cow numbers involved changed between seasons, and there were different confounding factors at work. The current trials at Dargaville, conducted by Northland interest groups, and at Dexcel will provide more information. Endophyte did not affect growth rates of bulls in a Manawatu study (Cosgrove et al. 1996), although feed intake was affected in one season. A smaller study in Northland showed depression of weight gain of yearling heifers and weaner bulls (mean of $21 \%$ in three summer-autumn experiments) and on one occasion, elevated respiration rates (Easton \& Couchman 1999). 
While visible heat stress is often observed with cattle, statistically significant effects on body temperature have not been recorded (Cosgrove et al. 1996; Blackwell \& Keogh 1999; Easton \& Couchman 1999).

Given the very serious effects of tall fescue on cattle performance in trials in USA, it had been expected that effects of ryegrass endophyte on cattle would be more marked. This has raised the possibility that factors other than ergovaline may contribute to the tall fescue situation (Lane et al. 1999).

\section{Seed management}

Prior to the discovery of the importance of endophyte, different seed lines of PRG had been reported to differ in their resistance to ASW (Kain et al. 1982). Seed lines of the same cultivar were present in commerce with markedly different levels of endophyte infection. Endophyte dies in stored seed unless the storage conditions are carefully controlled (Rolston et al. 1986). There can be catastrophic loss of endophyte viability in a few months if humidity is high. Critical upper limits in short term bulk storage for temperature, relative humidity $(\mathrm{RH})$ and seed moisture are $10^{\circ} \mathrm{C}$, $50 \%$ and $11 \%$ respectively. Seed stored below $5^{\circ} \mathrm{C}$, $50 \% \mathrm{RH}$ and $11 \%$ seed moisture has maintained viable endophyte levels for up to 15 years.

PRG seed crops are regularly treated with fungicide to control rust and other diseases. At the recommended rates, this use of fungicide does not affect seed endophyte infection (M.P.Rolston, 2000-2001 unpublished data), but as new fungicide products are introduced to the industry they need to be checked.

Fertiliser management of seed crops can also affect the endophyte status of the harvested seed, with a carryover effect in the subsequent sown swards (Stewart 1986).

\section{Endophyte biology}

Parallel with field studies has been work on the basic biology of the fungus and its interaction with its host grass. The endophyte species commonly present in PRG were characterised (Latch et al. 1984), and the variation (biodiversity) among endophyte strains found in different ryegrass and fescue species and populations has been analysed in New Zealand and abroad (Christensen et al. 1991; Christensen et al. 1993). Field work was facilitated by rapid immunological detection of the fungus (Musgrave 1984). Growth within the plant, and into the developing seed for transmission to the next grass generation was described (Philipson $\&$ Christey 1986), and the co-ordination of endophyte and host growth was high-lighted using a genetically transformed laboratory strain to precisely locate endophyte metabolic activity (Schmid \& Christensen 1999; Spiering 2000). The biochemical pathways leading to the production of lolitrem $\mathrm{B}$ are being elucidated (Scott et al. 1999).

\section{Selection of non-toxic endophyte strains}

Knowledge of the endophyte and its host has enabled a programme to manipulate and manage the association. There had been a long record of research on pasture management to minimise ryegrass staggers, and endophyte research was related back to this. The precise location in the plant of the fungus and of the different compounds it produces (Keogh et al. 1996), and the effects of different environmental variables on the fungus and its activity (Lane et al. 1997) have been identified. This has enabled a refining of management practices (Keogh \& Clements 1993).

The fungus can be isolated and grown in culture, and young seedlings can be artificially infected with it (Latch \& Christensen 1985). Endophyte strains isolated from PRG in New Zealand were largely similar in their chemistry, but some strains isolated from overseas PRG did not produce all the major compounds (Davies et al. 1993; Latch 1994). Transfer of strains to a different host showed that their properties to produce or not produce particular compounds were stable. However, the host plant can affect the amount of the compounds produced by the endophyte (Easton, Latch, Tapper \& Ball 2002 in press). Strains vary in their ability to form effective associations with a new host (Christensen et al. 1997), involving controlled growth into all new shoot meristems, efficient transmission into seed and good viability in stored seed. Ineffective strains may fail at any or all of these points. Likewise, plants vary in their suitability as a host for a transferred strain. Efficiency of inoculation and seed transmission, and production of compounds may all vary for one strain in different plant material (Easton et al. 2001).

\section{Selected strains in the field}

Endophyte strains from PRG have been identified which produce peramine but are free of ergovaline or lolitrem B or both (Fletcher et al. 1991; Latch 1994). "Endosafe" was released as a strain that produces no lolitrem B. It had supported apparently healthy sheep with no ryegrass staggers, and allowed ryegrass to grow and persist well (Fletcher et al. 1991). However, in PRG, it produced ergovaline at levels higher than those found in naturally infected, 
certified PRG cultivars. This was reflected in depressed liveweight gain, relative to sheep grazing endophyte-free PRG, elevated body temperatures and elevated respiration rates (Fletcher \& Easton 1997). It is no longer available in PRG, but has been retained in the market in the hybrid ryegrass 'Greenstone' where the level of ergovaline is relatively low, and no livestock health problems have been encountered.

AR1 strain is free of both ergovaline and lolitrem $\mathrm{B}$, and its effects on PRG agronomy and the health and productivity of grazing livestock have been intensively studied (Fletcher \& Easton 1997; Fletcher 1999; Popay et al. 1999; Fletcher \& Easton 2001). Sheep growth rates, lambing percentages, serum prolactin profiles, body temperatures, respiration rates and dag burdens are all the same as for sheep grazing PRG free of endophyte (Table 3). Mean herbage yield over several sites throughout New Zealand is significantly better for PRG infected with AR1 than for endophyte-free PRG (Popay et al. 1999). AR1 provides excellent protection against ASW. However, the protection provided against black beetle by AR1 is not always as robust as that provided by the naturally occurring endophyte (Popay \& Baltus 2001).

Table 3 Effects of ryegrass infected with selected endophyte strain AR1 on grazing sheep, relative to the same ryegrass cultivar infected with naturally occurring toxinproducing endophyte (WT) or free of endophyte (Nil) (results of Fletcher (1999)).

\begin{tabular}{llccc}
\hline & & WT & Nil & AR1 \\
\hline Lambs & LWG g/hd/day & $23^{\mathrm{a}}$ & $120^{\mathrm{b}}$ & $131^{\mathrm{b}}$ \\
& Rectal temp ${ }^{\circ} \mathrm{C}$ & $40.5^{\mathrm{a}}$ & $40.0^{\mathrm{b}}$ & $40.1^{\mathrm{b}}$ \\
& Respiration/min & $97^{\mathrm{a}}$ & $73^{\mathrm{b}}$ & $79^{\mathrm{b}}$ \\
& Serum prolactin ng/ml & $96^{\mathrm{a}}$ & $185^{\mathrm{b}}$ & $203^{\mathrm{b}}$ \\
& RGS, scale 1-5 & $3.2^{\mathrm{a}}$ & $0^{\mathrm{b}}$ & $0.3^{\mathrm{b}}$ \\
Hoggets & LWG g/hd/day & $165^{\mathrm{a}}$ & $191^{\mathrm{b}}$ & $212^{\mathrm{b}}$ \\
& Serum prolactin ng/ml & $101^{\mathrm{a}}$ & $333^{\mathrm{b}}$ & $344^{\mathrm{b}}$ \\
& Dags, scale 1-5 & $1.4^{\mathrm{a}}$ & $0.6^{\mathrm{b}}$ & $0.4^{\mathrm{b}}$ \\
\hline
\end{tabular}

a, b Means in the same row with different superscripts are significantly different at the $5 \%$ probability level.

The New Zealand seed industry has maintained an active interest in endophyte research, and has funded significant elements of it. Selected endophyte is available to New Zealand farmers through seed of the PRG cultivars developed and marketed by the different companies.

Establishment and management of pastures with selected endophyte, free of plants carrying toxic endophyte, requires preparation to minimise the load of buried seed (Hume \& Lyons 1992; Hume et al. 1999; Hume et al. 2001), and thorough field and seedbed preparation (van Vught \& Thom 1997; Burggraaf
\& Thom 2001). An initial modest presence of wildtype contaminants among the seedlings may increase under favourable natural selection (Francis \& Baird 1989; Hume \& Brock 1997; Burggraaf \& Thom 2001). Established pastures may be contaminated with seed from hay fed onto the pasture, or faeces of animals that have recently grazed toxic pastures with mature seedheads (van Vught \& Thom 1997; Burggraaf \& Thom 2001). A proportion of PRG seed passed in faeces between 10 and 36 hours after ingestion proved to be viable and to contain viable endophyte (Rolston et al. 2001). To avoid contaminating a field sown to PRG infected with selected endophyte, these authors recommended that stock have no access to PRG hay or PRG pasture with mature seedheads in the 36 hours prior to entering.

\section{Italian and hybrid ryegrasses}

The endophyte species characteristic of PRG is not normally found in Italian ryegrass. Another endophyte species ( $N$. occultans) is present in Italian ryegrass (Latch et al. 1988). It is much slower growing than the PRG endophyte, and does not proliferate as abundantly through the host tissue. There is evidence that the young seedling is protected from invertebrate attack (Stewart 1987; Piggot et al. 1988), but the $N$. occultans appears to have no effect on established pasture or on grazing livestock (Piggot et al. 1988; Prestidge 1991).

Perennial and Italian ryegrasses freely hybridise, and hybrid seed developed on the perennial parent may be infected with $N$. lolii. Hybrid ryegrass populations and cultivars may thus be infected with the PRG endophyte, and hybrid populations similar to Italian ryegrass have been identified which are infected with the PRG endophyte (Piggot et al. 1988).

\section{Tall fescue}

While the focus of New Zealand research has been PRG, the release of a selected non-toxic tall fescue endophyte ('Max-Q') in the USA, in partnership with University of Georgia and other American interests, is a successful by-product of our research. Endophytefree tall fescue is valuable in specific situations in New Zealand (Fraser \& Lyons 1994; Milne et al. 1997), but persistence and performance would be enhanced by an endophyte (Easton \& Cooper 1997). Tall fescue endophyte produces compounds other than those causing fescue toxicosis. Information to date indicates that 'Max-Q' supports excellent livestock production in the USA (Bouton et al. 2001), and in one New Zealand experiment (Fletcher et al. 2001). 
If these results are confirmed, selected non-toxic endophyte may greatly enhance the usefulness of tall fescue in New Zealand.

\section{Conclusion}

The revolutionary advance in our understanding of PRG pastures and the place of endophyte in them has impacted on pasture use and on seed inventory management. A new product, AR1, offers farmers greatly enhanced livestock production, certainly with sheep, and probably with cattle, particularly in districts where black beetle pressure is not serious. This represents a major achievement. The "Endosafe" strain in PRG does not cause ryegrass staggers and would provide better protection against black beetle than AR1, but livestock performance would not be as good. Clearly there remains the goal of better protection of the host grass but with livestock free to perform to their potential. The accumulated information, and our experience with endophyte strains, arm us well to pursue this goal.

\section{ACKNOWLEDGEMENTS}

It is a pleasure to acknowledge Liz Davies, Wayne Simpson, Tom Lyons and others who have worked directly with us, our AgResearch colleagues in the toxinology group at Ruakura, our peers working at Dexcel, at Massey and Lincoln Universities and in the seed industry, and the many friends we have made in the USA "fescue belt." We have received funding from the Foundation for Research, Science and Technology, and from Meat New Zealand.

\section{REFERENCES}

Ball, O.J.-P.; Miles, C.O.; Prestidge, R.A. 1997. Ergopeptine alkaloids and Neotyphodium loliimediated resistance in perennial ryegrass against adult Heteronychus arator (Coleoptera: Scarabaeidae). Journal of Economic Entomology 90: 1382-1391.

Ball, O.J.-P.; Prestidge, R.A. 1992. The effect of the endophytic fungus Acremonium lolii on adult black beetle (Heteronychus arator) feeding. Proceedings of the 45th New Zealand Plant Protection Conference: 201-204.

Ball, O.J.-P.; Prestidge, R.A.; Sprosen, J.M. 1993. Effect of plant age and endophyte viability on peramine and lolitrem $\mathrm{B}$ concentration in perennial ryegrass seedlings. Proceedings of the Second International Symposium on Acremonium/Grass Interactions: 63-65. Eds. Hume, D.E.; Latch,
G.C.M.; Easton, H.S., AgResearch, Palmerston North.

Barker, D.J.; Hume, D.E.; Quigley, P.E. 1997. Negligible physiological responses to water deficit of endophyte-infected and uninfected ryegrass. pp. 137-139. In: Neotyphodium/Grass Interactions. Eds. Bacon, C.W.; Hill, N.S. Plenum Press, New York \& London.

Barker, G.M.; Pottinger, R.P.; Addison, P.J. 1984a. Effect of Lolium endophyte fungus infections on survival of larval Argentine stem weevil. New Zealand Journal of Agricultural Research 27: 279281.

Barker, G.M.; Pottinger, R.P.; Addison, P.J.; Prestidge, R.A. 1984b. Effect of Lolium endophyte fungus infections on behaviour of adult Argentine stem weevil. New Zealand Journal of Agricultural Research 27: 271-277.

Blackwell, M.B.; Keogh, R.G. 1999. Endophyte toxins and performance of spring-calving dairy cows in Northland. Ryegrass endophyte: an essential New Zealand symbiosis. Grassland Research and Practice Series 7: 45-50.

Bouton, J.H.; Hill, N.S.; Hoveland, C.S.; McCann, M.A.; Thompson, F.N.; Hawkins, L.L.; Latch, G.C.M. 2001. Performance of tall fescue cultivars infected with non-toxic endophytes. Proceedings of the Grassland Conference 2000 - 4th International Neotyphodium/Grass Interactions Symposium: 179-185. Eds. Paul, V.H., Dapprich, P.D. Universität-Gesamthochschle Paderborn, Abteilung Soest, Fachbereich Agrarwirtschaft.

Burggraaf, V.T.; Thom, E.R. 2001. Sources of endophyte contamination in endophyte-free perennial ryegrass pastures after autumn spray-drilling. Proceedings of the Grassland Conference 2000 4th International Neotyphodium/Grass Interactions Symposium: 393-397. Eds. Paul, V.H., Dapprich, P.D. Universität-Gesamthochschle Paderborn, Abteilung Soest, Fachbereich Agrarwirtschaft.

Christensen, M.J.; Ball, O.J.P.; Bennett, R.J.; Schardl, C.L. 1997. Fungal and host genotype effects on compatibility and vascular colonization by Epichloe festucae. Mycological Research 101: 493-501.

Christensen, M.J.; Latch, G.C.M.; Tapper, B.A. 1991. Variation within isolates of Acremonium endophytes from perennial rye-grasses. Mycological Research 95: 918-923.

Christensen, M.J.; Leuchtmann, A.; Rowan, D.D.; Tapper, B.A. 1993. Taxonomy of Acremonium endophytes of tall fescue (Festuca arundinacea), meadow fescue ( $F$. pratensis) and perennial ryegrass (Lolium perenne). Mycological Research 97: 10831092. 
Clark, D.A.; Thom, E.R.; Waugh, C.D. 1996. Milk production from pastures and pasture silage with different levels of endophyte infection. Proceedings of the New Zealand Society of Animal Production 56: 292-296.

Cosgrove, G.P.; Anderson, C.B.; Berquist, T.R.N. 1996. Fungal endophyte effects on intake, health and liveweight gain of grazing cattle. Proceedings of the New Zealand Grassland Association 57: 4348.

Cunningham, I.J. 1958. Non-toxicity to animals of ryegrass endophyte and other endophytic fungi of New Zealand grasses. New Zealand Journal of Agricultural Research 1: 489-497.

Davies, E.; Lane, G.A.; Latch, G.C.M.; Tapper, B.A.; Garthwaite, I.; Towers, N.R.; Fletcher, L.R.; Pownall, D.B. 1993. Alkaloid concentrations in field-grown synthetic perennial ryegrass endophyte associations. Proceedings of the Second International Symposium on Acremonium/Grass Interactions: 72-76. Eds. Hume, D.E.; Latch, G.C.M.; Easton, H.S. AgResearch, Palmerston North.

Dymock, J.J.; Prestidge, R.A.; Rowan, D.D. 1989. The effects of lolitrem B on Argentine stem weevil larvae. Proceedings of the Forty Second New Zealand Weed and Pest Control Conference: 7375.

Easton, H.S.; Cooper, B.M. 1997. Field performance of tall fescue with low infection with Neotyphodium endophyte. pp. 251-253. In: Neotyphodium/Grass Interactions. Eds. Bacon, C.W.; Hill, N.S. Plenum Press, New York \& London.

Easton, H.S.; Cooper, B.M.; Lyons, T.B.; Pennell, C.G.L.; Popay, A.J.; Tapper, B.A.; Simpson, W.R. 2001. Selected endophyte and plant variation. Proceedings of the Grassland Conference 2000 4th International Neotyphodium/Grass Interactions Symposium 351-356. Eds. Paul, V.H., Dapprich, P.D. Universität-Gesamthochschle Paderborn, Abteilung Soest, Fachbereich Agrarwirtschaft.

Easton, H.S.; Couchman, J.N. 1999. Ryegrass endophyte and cattle growth in Northland. Ryegrass endophyte: an essential New Zealand symbiosis. Grassland Research and Practice Series 7: 57-62.

Easton, H.S.; Lane, G.A.; Tapper, B.A.; Keogh, R.G.; Cooper, B.M.; Blackwell, M.; Anderson, M.; Fletcher, L.R. 1996. Ryegrass endophyte-related heat stress in cattle. Proceedings of the New Zealand Grassland Association 57: 37-41.

Eerens, J.P.J.; Lucas, R.J.; Easton, H.S.; White, J.G.H. 1998a. Influence of the ryegrass endophyte (Neotyphodium lolii) in a cool moist environment. I. Pasture production. New Zealand Journal of Agricultural Research 41: 39-48.
Eerens, J.P.J.; Visker, M.H.P.W.; Lucas, R.J.; Easton, H.S.; White, J.G.H. 1998b. Influence of the ryegrass endophyte (Neotyphodium lolii) in a cool-moist environment. IV. Plant parasitic nematodes. New Zealand Journal of Agricultural Research 41: 209217.

Fletcher, L.R. 1982. Observations of ryegrass staggers in weaned lambs grazing different ryegrass pastures. New Zealand Journal of Experimental Agriculture 10: 203-207.

Fletcher, L.R. 1983. Effects of presence of Lolium endophyte on growth rates of weaned lambs, growing on to hoggets, on various ryegrasses. Proceedings of the New Zealand Grassland Association 44: 237-239.

Fletcher, L.R. 1993. Grazing ryegrass/endophyte associations and their effect on animal health and performance. Proceedings of the Second International Symposium on Acremonium/Grass Interactions: plenary papers: 115-120. Eds. Hume, D.E.; Latch, G.C.M.; Easton, H.S. AgResearch, Palmerston North.

Fletcher, L.R. 1999. "Non-toxic" endophytes in ryegrass and their effect on livestock health and production. Ryegrass endophyte: an essential New Zealand symbiosis. Grassland Research and Practice Series 7: 133-139.

Fletcher, L.R.; Fletcher, C.G.; Sutherland, B.L. 2001. The health and performance of sheep grazing a non-toxic tall fescue endophyte association. Proceedings of the Grassland Conference 2000 - 4th International Neotyphodium/Grass Interactions Symposium: 459-464. Eds. Paul, V.H., Dapprich, P.D. Universität-Gesamthochschle Paderborn, Abteilung Soest, Fachbereich Agrarwirtschaft.

Fletcher, L.R.; Barrell, G.K. 1984. Reduced liveweight gains and serum prolactin levels in hoggets grazing ryegrasses containing Lolium endophyte. New Zealand Veterinary Journal 32: 139-140.

Fletcher, L.R.; Easton, H.S. 1997. The evaluation and use of endophytes for pasture improvement. pp. 209-227. In: Neotyphodium/Grass Interactions. Eds. Bacon, C.W.; Hill, N.S. Plenum Press, New York \& London.

Fletcher, L.R.; Easton, H.S. 2001. Advances in endophyte research. Progress and priorities in temperate areas. Proceedings of the XIX Inter- national Grassland Congress: 595-603.

Fletcher, L.R.; Harvey, I.C. 1981. An association of a Lolium endophyte with ryegrass staggers. New Zealand Veterinary Journal 29: 185-186.

Fletcher, L.R.; Popay, A.J.; Tapper, B.A. 1991. Evaluation of several lolitrem-free endophyte/ perennial ryegrass combinations. Proceedings of 
the New Zealand Grassland Association 53: 215219.

Fletcher, L.R.; Sutherland, B.L.; Fletcher, C.G. 1997. Effect of ambient and black-globe temperature on plasma prolactin levels in ewes grazing endophytefree and endophyte infected ryegrass. pp. 425427. In: Neotyphodium/Grass Interactions. Eds. Bacon, C.W.; Hill, N.S. Plenum Press, New York.

Fletcher, L.R.; Sutherland, B.L.; Fletcher, C.G. 1999. The impact of endophyte on the health and productivity of sheep grazing ryegrass-based pastures. Ryegrass endophyte: an essential New Zealand symbiosis. Grassland Research and Practice Series 7: $11-17$.

Francis, S.M.; Baird, D.B. 1989. Increase in the proportion of endophyte-infected perennial ryegrass plants in overdrilled pastures. New Zealand Journal of Agricultural Research 32: 437-440.

Fraser, T.J.; Lyons, T.B. 1994. Grasslands Advance tall fescue establishment and animal performance. Proceedings of the New Zealand Grassland Association 56: 117-119.

Gallagher, R.T.; White, E.P.; Mortimer, P.H. 1981. Ryegrass staggers: Isolation of potent neurotoxins lolitrem A and lolitrem B from staggers producing pastures. New Zealand Veterinary Journal 29: 189190.

Gaynor, D.L.; Hunt, W.F. 1983. The relationship between nitrogen supply, endophytic fungus, and Argentine stem weevil resistance in ryegrasses. Proceedings of the New Zealand Grassland Association 44: 257-263.

Hume, D.E.; Brock, J.L. 1997. Increases in endophyte incidence in perennial ryegrass at Palmerston North, Manawatu, New Zealand. pp. 61-63. In: Neotyphodium/Grass Interactions. Eds. Bacon, C.W.; Hill, N.S. Plenum Press, New York \& London.

Hume, D.E.; Lyons, T.B. 1992. Establishment of new pastures free of ryegrass contamination. Proceedings of the New Zealand Grassland Association 54: 151-156.

Hume, D.E.; Popay, A.J.; Barker, D.J. 1993. Effect of Acremonium endophyte on growth of ryegrass and tall fescue under varying levels of soil moisture and Argentine stem weevil attack. Proceedings of the Second International Symposium on Acremonium/Grass Interactions: 161-164. Eds. Hume, D.E.; Latch, G.C.M.; Easton, H.S., AgResearch, Palmerston North.

Hume, D.E.; Rolston, M.P.; Baird, D.B.; Archie, W.A.; Marsh, M.R. 2001. Endophyte-infected ryegrass seed in soil as a potential source of endophyte contamination of new pastures. Proceedings of the Grassland Conference 2000 - 4th International
Neotyphodium/Grass Interactions Symposium: $97-$ 102. Eds. Paul, V.H., Dapprich, P.D. UniversitätGesamthochschle Paderborn, Abteilung Soest, Fachbereich Agrarwirtschaft.

Hume, D.E.; Rolston, M.P.; Baird, D.J.; Archie, W.J.; Marsh, M.R. 1999. Survival of endophyte-infected ryegrass seed buried in soil. Ryegrass endophyte: an essential New Zealand symbiosis. Grassland Research and Practice Series 7: 51-156.

Hunt, W.F.; Easton, H.S. 1989. Fifty years of ryegrass research in New Zealand. Proceedings of the New Zealand Grassland Association 50: 11-23.

Kain, W.M.; Wyeth, T.K.; Gaynor, D.L.; Slay, M.W. 1982. Argentine stem weevil (Hyperodes bonariensis Kuschel) resistance in perennial and hybrid ryegrasses. New Zealand Journal of Agricultural Research 25: 255-259.

Keogh, R.G.; Blackwell, M.B. 2001. A three-year investigation of the performance of spring-calving dairy cows grazing ryegrass-based pastures of high or low endophyte toxin status in Northland. Proceedings of the New Zealand Grassland Association 63: 209-214.

Keogh, R.G.; Clements, R.J. 1993. Grazing management: a basis for control of ryegrass staggers. Proceedings of the Second International Symposium on Acremonium/Grass Interactions: 129-131. Eds. Hume, D.E.; Latch, G.C.M.; Easton, H.S., AgResearch, Palmerston North.

Keogh, R.G.; Tapper, B.A.; Fletcher, R.H. 1996. Distributions of the fungal endophyte Acremonium lolii, and of the alkaloids lolitrem B and peramine, within perennial ryegrass. New Zealand Journal of Agricultural Research 39: 121-127.

Lane, G.A.; Christensen, M.J.; Miles, C.O. 2000. Coevolution of fungal endophytes with grasses: the significance of secondary metabolites. pp. 341388. In: Microbial Endophytes. Eds. Bacon, C.W.; White, J.F. Marcel Dekker, New York.

Lane, G.A.; Tapper, B.A.; Davies, E. 1999. Ergot alkaloids additional to ergovaline in endophyteinfected perennial ryegrass and tall fescue in New Zealand. Ryegrass endophyte: an essential New Zealand symbiosis. Grassland Research and Practice Series 7: 95-100.

Lane, G.A.; Tapper, B.A.; Davies, E.; Hume, D.E.; Latch, G.C.M.; Barker, D.J.; Easton, H.S.; Rolston, M.P. 1997. Effect of growth conditions on alkaloid concentrations in perennial ryegrass naturally infected with endophyte. pp. 179-182. In: Neotyphodium/Grass Interactions. Eds. Bacon, C.W.; Hill, N.S. Plenum Press, New York \& London.

Latch, G.C.M. 1994. Influence of Acremonium endophytes on perennial grass improvement. New 
Zealand Journal of Agricultural Research 37: 311318.

Latch, G.C.M.; Christensen, M.J. 1985. Artificial infection of grasses with endophytes. Annals of Applied Biology 107: 17-24.

Latch, G.C.M.; Christensen, M.J.; Hickson, R.E. 1988. Endophytes of annual and hybrid ryegrasses. New Zealand Journal of Agricultural Research 31: 57-63.

Latch, G.C.M.; Christensen, M.J.; Samuels, G.J. 1984. Five endophytes of Lolium and Festuca in New Zealand. Mycotaxon 20: 535-550.

Latch, G.C.M.; Hunt, W.F.; Musgrave, D.R. 1985. Endophytic fungi affect growth of perennial ryegrass. New Zealand Journal of Agricultural Research 28: 165-168.

McLeay, L.M.; Smith, B.L. 1999. Effects of the mycotoxins lolitrem B and paxilline on gastrointestinal smooth muscle, the cardiovascular and respiratory systems, and temperature in sheep. Ryegrass endophyte: an essential New Zealand symbiosis. Grassland Research and Practice Series 7: 69-75.

Miles, C.O.; Munday, S.C.; Wilkins, A.L.; Ede, R.M.; Towers, N.R. 1994. Large-scale isolation of lolitrem $\mathrm{B}$ and structure determination of lolitrem E. Journal of Agricultural and Food Chemistry 42: 1488-1492.

Milne, G.D.; Shaw, R.; Powell, R.; Pirie, B.; Pirie, J. 1997. Tall fescue use on dairy farms. Proceedings of the New Zealand Grassland Association 59: 163-167.

Morris, C.A.; Towers, N.R.; Amyes, N.C. 1999. Six years of selection responses for resistance or susceptibility to ryegrass staggers in sheep. Ryegrass endophyte: an essential New Zealand symbiosis. Grassland Research and Practice Series 7: 27-31.

Mortimer, P.H.; di Menna, M. 1983. Ryegrass staggers: further substantiation of a Lolium endophyte aetiology and the discovery of weevil resistance of ryegrass pastures infected with Lolium endophyte. Proceedings of the New Zealand Grassland Association 44: 240-243.

Munday-Finch, S.C.; Garthwaite, I. 1999. Toxicology of ryegrass endophyte in livestock. Ryegrass endophyte: an essential New Zealand symbiosis. Grassland Research and Practice Series 7: 63-67.

Musgrave, D.R. 1984. Detection of an endophytic fungus of Lolium perenne using enzyme-linked immunosorbent assay (ELISA). New Zealand Journal of Agricultural Research 27: 283-288.

Neill, J.C. 1941. The endophytes of Lolium and Festuca. New Zealand of Journal Science and Technology A23: 185-193.

Pennell, C.G.; Ball, O.J.-P. 1999. The effects of Neotyphodium endophytes in tall fescue on pasture mealy bug (Balanococcus poae). Proceedings of the 52nd Conference of the New Zealand Plant Protection Society: 259-263.

Philipson, M.N.; Christey, M.C. 1986. The relationship of host and endophyte during flowering, seed formation, and germination of Lolium perenne. New Zealand Journal of Botany 24: 125-134.

Piggot, G.J.; Morgan, H.M.; Bakker, R.J. 1988. Endophytes in Northland ecotypes of hybrid ryegrass. Proceedings of the 41st New Zealand Weed and Pest Control Conference: 129-131.

Popay, A.J.; Baltus, J.G. 2001. Black beetle damage to perennial grass infected with AR1 endophyte. Proceedings of the New Zealand Grassland Association 63: 267-271.

Popay, A.J.; Baltus, J.G.; Pennell, C.G.L. 2001. Insect resistance in perennial ryegrass infected with toxinfree Neotyphodium endophytes. Proceedings of the Grassland Conference 2000 - 4th International Neotyphodium/Grass Interactions Symposium: 187193. Eds. Paul, V.H., Dapprich, P.D. UniversitätGesamthochschle Paderborn, Abteilung Soest, Fachbereich Agrarwirtschaft.

Popay, A.J.; Hume, D.E.; Baltus, J.G.; Latch, G.C.M.; Tapper, B.A.; Lyons, T.B.; Cooper, B.M.; Pennell, C.G.; Eerens, J.P.J.; Marshall, S.L. 1999. Field performance of perennial ryegrass (Lolium perenne) infected with toxin-free fungal endophytes (Neotyphodium spp). Ryegrass endophyte: an essential New Zealand symbiosis. Grassland Research and Practice Series 7: 113-122.

Popay, A.J.; Prestidge, R.A.; Rowan, D.D.; Dymock, J.J. 1990. The role of Acremonium lolii mycotoxins in insect resistance of perennial ryegrass (Lolium perenne). Proceedings of the International Symposium Acremonium/Grass Interactions: 44-46. Eds. Quisenberry, S.S.; Joost, R.E., Louisiana Agricultural Experimental Station, Baton Rouge.

Popay, A.J.; Rowan, D.D. 1994. Endophytic fungi as mediators of plant-insect interactions. pp. 83-103. In: Insect-Plant Interactions. Ed. Bernays, E.A. CRC Press.

Pownall, D.B.; Lucas, R.J.; Familton, A.S.; Love, B.G.; Fletcher, L.R. 1993. Endophyte associated mycotoxins and diarrhoea in lambs. Proceedings of the Second International Symposium on Acremonium/Grass Interactions: 132-134. Eds. Hume, D.E.; Latch, G.C.M.; Easton, H.S., AgResearch, Palmerston North.

Prestidge, R.A. 1991. Susceptibility of Italian ryegrasses (Lolium multiflorum Lam.) to Argentine stem weevil (Listronotus bonariensis Kuschel) feeding and oviposition. New Zealand Journal of Agricultural Research 34: 119-125. 
Prestidge, R.A.; Ball, O.J.P. 1993. The role of endophytes in alleviating plant biotic stress in New Zealand. Proceedings of the Second International Symposium on Acremonium/Grass Interactions: plenary papers: 141-151. Eds. Hume, D.E.; Latch, G.C.M.; Easton, H.S. AgResearch, Palmerston North.

Prestidge, R.A.; Marshall, S.L. 1997. The effects of Acremonium-infected perennial ryegrass on the abundance of invertebrate predators. pp. 195-197. In: Neotyphodium/Grass Interactions. Eds. Bacon, C.W.; Hill, N.S. Plenum Press, New York \& London.

Prestidge, R.A.; Marshall, S.L.; Thom, E.R.; M, O.C. 1997. Seasonal earthworm densities on endophyteinfected and endophyte-free perennial ryegrass. Proceedings of the Fiftieth New Zealand Plant Protection Conference: 73-77.

Prestidge, R.A.; Pottinger, R.P.; Barker, G.M. 1982. An association of Lolium endophyte with ryegrass resistance to Argentine stem weevil. Proceedings of the 35th New Zealand Weed and Pest Control Conference: 119-122.

Prestidge, R.A.; Thom, E.R.; Marshall, S.L.; Taylor, M.J.; Willoughby, B.; Wildermoth, D.D. 1992. Influence of Acremonium lolii infection in perennial ryegrass on germination, emergence, survival, and growth of white clover. New Zealand Journal of Agricultural Research 35: 225-234.

Rolston, M.P.; Fletcher, L.R.; Fletcher, C.G.; Archie, W.A. 2001. The viability of perennial ryegrass seed and its endophyte in sheep faeces. Proceedings of the Grassland Conference 2000 - 4th International Neotyphodium/Grass Interactions Symposium: 405-408. Eds. Paul, V.H., Dapprich, P.D. Universität-Gesamthochschle Paderborn, Abteilung Soest, Fachbereich Agrarwirtschaft.

Rolston, M.P.; Hare, M.D.; Moore, K.K.; Christensen, M.J. 1986. Viability of Lolium endophyte fungus in seed stored at different moisture contents and temperatures. New Zealand Journal of Experimental Agriculture 14: 297-300.

Rowan, D.D.; Gaynor, D.L. 1986. Isolation of feeding deterrents against Argentine stem weevil from ryegrass infected with the endophyte Acremonium loliae. Journal of Chemical Ecology 12: 647-658.

Rowan, D.D.; Shaw, G.J. 1987. Detection of ergopeptine alkaloids in endophyte-infected perennial ryegrass by tandem mass spectrometry. New Zealand Veterinary Journal 35: 197-198.

Sampson, K. 1933. The systemic infection of grasses by Epichloë typhina (Pers.) Tul. Transactions of the British Mycological Society 18: 30-47.

Schmid, J.; Christensen, M.J. 1999. Ryegrass endophyte: host/fungus interaction. Ryegrass endophyte: an essential New Zealand symbiosis. Grassland Research and Practice Series 7: 101-106.

Scott, D.B.; Young, C.L.; McMillan, L. 1999. Molecular biology of Epichloë endophyte toxin biosynthesis. Ryegrass endophyte: an essential New Zealand sym- biosis. Grassland Research and Practice Series 7: 77-83.

Spiering, M.J. 2000. Distribution of Neotyphodium lolii-endophyte metabolic activity in perennial ryegrass (Lolium perenne L.) and its implications for alkaloid distribution and photosynthesis. Ph.D. thesis, Massey University.

Stevens, D.R.; Hickey, M.J. 1990. Effects of endophytic ryegrass on the production of ryegrass-white clover pastures. Proceedings of the International Symposium on Acremonium/Grass Interactions: 5861. Eds. Quisenberry, S.S.; Joost, R.E., Louisiana Agricultural Experimental Station, Baton Rouge.

Stewart, A.V. 1985. Perennial ryegrass seedling resistance to Argentine stem weevil. New Zealand Journal of Agricultural Research 28: 403-407.

Stewart, A.V. 1986. Effect on the Lolium endophyte of nitrogen applied to perennial ryegrass seed crops. New Zealand Journal of Experimental Agriculture 14: 393-397.

Stewart, A.V. 1987. Plant-breeding aspects of ryegrass (Lolium spp.) infected with endophytic fungus. Ph.D. thesis, Lincoln College, Canterbury University.

Stewart, T.M.; Mercer, C.F.; Grant, J.L. 1993. Development of Meloidogyne naasi on endophyteinfected and endophyte-free perennial ryegrass. Australasian Plant Pathology 22: 40-41.

Sutherland, B.L.; Hoglund, J.H. 1989. Effect of ryegrass containing the endophyte (Acremonium lolii), on the performance of associated white clover and subsequent crops. Proceedings of the New Zealand Grassland Association 50: 265-269.

Sutherland, B.L.; Hume, D.E.; Tapper, B.A. 1999. Allelopathic effects of endophyte-infected perennial ryegrass extracts on white clover seedlings. New Zealand Journal of Agricultural Research 42: 1926.

Thom, E.R.; Clark, D.A.; Waugh, C.D. 1999. Endophyte and dairy production in New Zealand: experience at the Dairying Research Corporation. Ryegrass endophyte: an essential New Zealand symbiosis. Grassland Research and Practice Series 7: 39-44.

van Vught, V.T.; Thom, E.R. 1997. Ryegrass contamination of endophyte-free dairy pastures after spray-drilling in autumn. Proceedings of the New Zealand Grassland Association 59: 233-237.

Watson, R.N. 1990. Effects of plant nematodes and Acremonium endophyte on white clover establishment with ryegrass or tall fescue. Proceedings of the Forty Third New Zealand Weed and Pest Control Conference: 347-351.

Watson, R.N.; Hume, D.E.; Bell, N.L.; Neville, F.J.; Popay, A.J. 1995. Plant-parasitic nematodes associated with perennial ryegrass and tall fescue with and without Acremonium endophyte. Proceedings of the Forty Eighth New Zealand Plant Protection Conference: 199-203. 